\title{
Bienes comunales: naturaleza jurídica y necesidad de una nueva orientación en su régimen de aprovechamiento
}

\author{
Isabel González Ríos \\ Profesora de Derecho Administrativo \\ de la Universidad de Málaga
}

Sumario: 1. NATURALEZA JURÍDICA DE LOS BIENES COMUNALES. A. Naturaleza sui generis. B. Naturaleza demanial. 2. PROBLEMÁTICA EN TORNO A LA NATURALEZA DEMANIAL DE LOS BIENES COMUNALES. A. Titularidad. a) Exclusivamente vecinal; b) Compartida; c) Municipal. B. La afectación peculiar de los bienes comunales. 3. PROTOTIPO DE BIEN COMUNAL: LOS MONTES MUNICIPALES. A. Clasificación. B. Necesidad de una afectación comunal más rentable económica y socialmente. 4. RECAPITULACIÓN.

\section{NATURALEZA JURÍDICA DE LOS BIENES COMUNALES}

En la medida en que tanto de la $\mathrm{CE}$ como de la normativa de régimen local estatal se deduce que existen bienes, los comunales, que aunque se integran en el Título VI, Capítulo 1. ${ }^{\circ}$, de la LBRL de 1985 y del TRRL de 1986, que regulan los «bienes de las Entidades Locales» ${ }^{1}$, no queda claro

\footnotetext{
${ }^{1}$ La Constitución española de 1978 establece que «la ley regulará el régimen jurídico de los bienes de dominio público y de los comunales, inspirándose en los principios de inalienabilidad, imprescriptibilidad e inembargabilidad, así como su desafectación» (art. 132.1).

Esta reserva de ley impide, según reiterada jurisprudencia del Tribunal Supremo, el que un reglamento transgreda el marco legal establecido en la correspondiente regulación legal. En este sentido pueden verse las Sentencias de 17 de julio de 1992 (Ar. 6473; Pte.: Jorge Rodríguez Zapata Pérez, FJ 1. ${ }^{\circ}$ ), de 10 de julio de 1992 (Ar. 6258; Pte.: Eladio Escusol Barra, FJ 4. ${ }^{\circ}$ ), de 22 de julio de 1992 (Ar. 6581; Pte.: M. Baena del Alcázar, FJ 2. y 3. ${ }^{\circ}$ ), de 23 de octubre de 1992 (Ar. 8103; Pte.: E. Escusol Barra, FJ 2. ${ }^{\circ}$ ), de 20 de mayo de 1992 (Ar. 4462; Pte.: M. Baena del Alcázar, FJ 2. ${ }^{\circ}$ ) y, de 14 de noviembre de 1995 (Ar. 8567; Pte.: J. García Estartús, FJ 2. ${ }^{\circ}$ ); todas ellas relativas a una Ordenanza municipal sobre aprovechamiento de pastos que contradice la regulación establecida en la Ley Foral Navarra de 1986 de regulación de los bienes comunales, al exceder la regulación contenida en ésta, imponiendo más condiciones para poder participar en el concurso de adjudicación de pastos.
}

La regulación legal de los bienes comunales la encontramos en la legislación básica del Estado (LBRL, arts. 79.3 y 80.1), así como en la correspondiente legislación autonómica reguladora de los bienes locales. Junto a esta normativa encontramos una importante regulación estatal supletoria de estos bienes en:

—El TRRL'86 (arts. 75, 77 y 78), cuyo carácter básico no aparece claramente determinado, como se infiere de la DF 7. .a del mismo.

— El RBEL'86 (arts. 2, 3, 4, 5 y 94-108). 
en qué medida el municipio es titular de los mismos ni cuál sea su afectación; o sea, no queda claro su carácter demanial, vamos a tratar de determinar cuál sea su naturaleza jurídica.

Conviene aclarar la situación de estos bienes, en la medida en que si concluimos que son bienes de dominio público municipal, hay que aclarar en virtud de qué afectación y, consiguientemente, cuál es la explotación económica que el municipio puede realizar de los mismos.

Son abundantes los estudios doctrinales que centran su atención en los bienes comunales ${ }^{2}$; cabe destacar cómo estos bienes comunales, entre los cuales se sitúan concretamente muchos de los montes municipales, se consideraban en un principio en la legislación que los regulaba, y la jurisprudencia que la interpretaba como una especie de los bienes patrimoniales, pero con un régimen jurídico prácticamente idéntico al de los bienes de dominio público ${ }^{3}$.

2 A. Nieto García, Bienes comunales, Ed. Revista de Derecho Privado, Madrid, 1964. L. Martín Retortillo Baquer, «En torno a los bienes comunales», RAP n. ${ }^{\circ} 84.1977$, pp. 429 y ss. R. Altamira y Crevea, Historia de la propiedad comunal; Instituto de Estudios de Administración Local, Madrid, 1981. Col. Administración y ciudadano, n. ${ }^{\circ}$ 15. Nemesio Rodríguez Moro, «Los bienes comunales tienen como titular al respectivo municipio, sin que pueda atribuirse tal titularidad a una junta vecinal administrativa de los mismos que venía funcionando al efecto», REALA n. ${ }^{\circ} 214,1982$, p. 347. GARCIA DE ENTERRÍA, Las formas comunitarias de la propiedad forestal y su posible proyección futura, Ed. Estudio, Santander, 1986. Eloy Colom Piazuelo, Los bienes comunales en la legislación de régimen local, Ed. Tecnos, Madrid, 1994. A. EMBiD Irujo, La defensa de los comunales, Ed. Civitas, S. A. Madrid, 1994. F. SAInz Moreno, «Artículo 132. Dominio público, bienes comunales, Patrimonio del Estado y Patrimonio Nacional», en Comentarios a la Constitu-

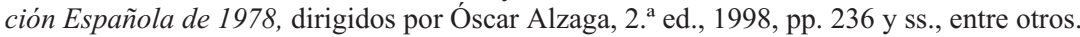

3 J. M. de la Cuétara, La actividad de la Administración, Ed. Tecnos, S. A., Madrid, 1983, p. 504, sostiene que de la Ley de Régimen Local y del Reglamento de Bienes no cabe duda de que los bienes comunales son bienes patrimoniales del municipio.

Así, el artículo 183 LRL'55 establecía que: «Los bienes municipales se clasifican en bienes de dominio público y patrimoniales... Los patrimoniales son de propios o comunales».

Por su parte, la jurisprudencia del Tribunal Supremo tiene reiterada doctrina sobre el carácter patrimonial de los bienes comunales. Sirvan de muestra las sentencias:

— De 8 de noviembre de 1977 (Ar. 4159; Pte.: Pedro Martín de Hijos y Muñoz, FJ 2. ${ }^{\circ}$ ). La sentencia apelada, cuyos fundamentos jurídicos acepta el Tribunal Supremo, sostiene que «los bienes comunales, dada su naturaleza patrimonial [arts. 182, 183 y 187 de la LRL (RC 1956...) y 5 del Reglamento de Bienes (RC 1956...)], y su pertenencia a las Entidades Locales en régimen de derecho privado, son susceptibles de expropiación...».

— De 15 de marzo de 1980 (Ar. 1800; Pte.: P. Martín Martín, cdo. 3. ${ }^{\circ}$ ).

— De 9 de junio de 1986 (Ar. 6609; Pte.: J. García Estartús, FJ 1.º), se refiere a la «condición jurídico-administrativa civil de los bienes patrimoniales de comunales...».

Esta calificación de los bienes comunales como patrimoniales no impide al Tribunal afirmar su sometimiento a un régimen jurídico de Derecho público, así como que su aprovechamiento se sujeta a 
REAL-2001, núm. 286-287. GONZÁLEZ RÍOS. BIENES COMUNALES: NATURALEZA JURÍDICA Y ...

BIENES COMUNALES: NATURALEZA JURÍDICA Y NECESIDAD...

A partir de la publicación de la Constitución española de 1978, de la LBRL de 1985 y de sus normas de desarrollo, parece quedar claro que los bienes comunales son una categoría jurídica distinta a la de los bienes patrimoniales. Ahora bien, ¿son los bienes comunales bienes de dominio público? Diversas son las posturas sostenidas al respecto:

\section{A. Naturaleza sui generis de los bienes comunales}

En esta línea se sitúa un sector doctrinal ${ }^{4}$ que estima que los bienes comunales no son patrimoniales porque su régimen jurídico es prácticamente el de los bienes de dominio público, pero estima que tampoco son de dominio público puesto que su titularidad no es exclusiva del municipio, sino que se trata de una titularidad compartida entre éste y los vecinos. Así, los comunales constituyen «un auténtico quid aliud, no encajable en ninguna de las fórmulas jurídicas patrimoniales públicas convencionales».

En apoyo de esta tesis doctrinal el Tribunal Constitucional ha afirmado la «naturaleza jurídica peculiar» que tienen este tipo de bienes. En este sentido, la STC de 2 de febrero de 1981 establece que «los bienes comunales tienen la naturaleza jurídica peculiar que ha dado lugar a que la $\mathrm{CE}$ haga una especial referencia a los mismos en el artículo 132.1 al reservar a la ley la regulación de su régimen jurídico que habrá de inspirarse en los principios de inalienabilidad, imprescriptibilidad e inembargabilidad».

Cabe destacar cómo el Consejo de Estado también atribuye a los bienes comunales una naturaleza sui generis. Así, en el Dictamen de 13 de julio de $1995^{5}$ viene a sostener que los bienes comunales, a pesar de que «en la concepción que luce en el artículo 132 de la Constitución están más cerca de los (bienes) de dominio público, y en la Ley de Bases de Ré-

normas de Derecho administrativo en la Sentencia de 17 de mayo de 1982 (Ar. 3903; Pte.: Aurelio Botella Taza, cdo. $3 .^{\circ}$ y $4 .^{\circ}$ ).

${ }^{4}$ Raúl Bocanegra Sierra, «Sobre algunos aspectos de la desafectación de comunales», RAP n. ${ }^{\circ} 100-102$, v. $3 .^{\circ}, 1983$, pp. 2227 y ss. Tomás CoBo Olvera, Régimen jurídico de los bienes de las Entidades Locales, Ed. Bayer Hnos., S. A., Barcelona (1982, p. 62), sostiene que los bienes comunales y los de dominio público son dos categorías distintas. Y ello porque en los bienes comunales la titularidad no es exclusiva de la Entidad Local, sino compartida con los vecinos, y el destino es el aprovechamiento de los vecinos. En el mismo sentido, Aurelio GuATta, Derecho Administrativo. Aguas, montes, minas, Ed. Civitas, S. A., Madrid, 1982, p. 285, mantiene que los bienes comunales por su régimen jurídico se asemejan a los bienes de dominio público, pero no participan de esta naturaleza dada la titularidad compartida de los mismos (municipios-vecinos) y porque sólo los vecinos pueden aprovecharlos, excluyéndose radicalmente al público en general. F. SAINZ Moreno, «Artículo 132. Dominio público, bienes comunales...», op. cit., pp. 236-237.

${ }^{5}$ Consejo de Estado, Recopilación de Doctrina legal 1995, pp. 601 y ss. Dictamen n. ${ }^{0} 1528 / 95$, de 13 de julio. 
gimen Local se opera un acercamiento de los bienes comunales al dominio público, aquéllos siguen conservando rasgos propios que los diferencian de los bienes de dominio público stricto sensu, calificándose los comunales como aquellos cuyo aprovechamiento corresponda al común de los vecinos».

\section{B. Naturaleza demanial}

Un importante sector doctrinal considera que los bienes comunales son bienes de dominio público, amparándose fundamentalmente en la regulación normativa que de los mismos se hace actualmente ${ }^{6}$.

Por su parte, la jurisprudencia del Tribunal Supremo ha sostenido la equiparación en el régimen jurídico de los bienes demaniales y de los comunales en la Sentencia de 18 de noviembre de $1996^{7}$, a la vez que la Sentencia de 21 de septiembre de 1999 mantiene el carácter demanial de los bienes comunales ${ }^{8}$.

Efectivamente, de la regulación de los bienes comunales puede deducirse su naturaleza demanial. Así, el artículo $132 \mathrm{CE}$ les atribuye la naturaleza de inalienables, imprescriptibles e inembargables ${ }^{9} \mathrm{y}$ los sitúa jun-

\footnotetext{
${ }^{6}$ Así son calificados en Nuevo Régimen Local, El Consultor de los Ayuntamientos y de los juzgados, Madrid (1986, p. 707). En esta medida se considera que «la principal innovación introducida por la LBRL en materia de bienes es la de haber incluido los comunales entre los bienes de dominio público, cuando tradicionalmente eran considerados patrimoniales».
}

También califican como bienes de dominio público a los comunales autores como A. NiETo GARCía, «La nueva regulación de los bienes comunales», REALA n. ${ }^{\circ} 233$ (1986-1987, p. 13). J. Climent BarberÁ, Legislación de Régimen Local. Ley 7/1985. RD-L 781/1986, Generalitat Valenciana, 1987, pp. 235-236. A. Ballester, Martínez Pallarés y otros, en Manual básico de Administración Local, Ed. Aranzadi (1992, p. 53). Ello, en virtud de la regulación que sobre ellos se recoge en la LBRL y en el RBEL. También M. ${ }^{a}$ Bellido BARRIonuevo y otros, Derecho Administrativo II. Parte Especial. Ed. Universitas, S. A., Madrid, 1998, p. 388.

Para F. Sainz Moreno, «Los bienes de las Entidades Locales» en Tratado de Derecho Municipal II, dirigido por S. Muñoz Machado, Ed. Civitas, S. A., Madrid, 1988, p. 1594, de los artículos 79 y 80.1 de la LBRL se deduce el carácter de bienes de dominio público de los bienes comunales.

${ }^{7}$ STS de 18 de noviembre de 1996 (Ar. 9620; Pte.: Mariano Baena del Alcázar, FJ 1. ${ }^{\circ}$ ).

${ }^{8}$ La Sentencia de 21 de septiembre de 1999 (Ar. 7925; Pte.: J. J. González Rivas; FJ 7. ํ) sostiene que cabe admitir la desafectación tácita por el transcurso de 25 años sin utilizarse un bien (monte) en el sentido de su afectación comunal, tal como se preveía en el artículo 8.5 del Reglamento de Bienes de las Corporaciones Locales de 1955, añadiendo el Tribunal Supremo que de esta manera el bien comunal se covierte en bien de propios, «lo cual se traduce en un efecto de la desafectación que hace cesar el carácter de dominio público convirtiéndolo en bienes patrimoniales...».

9 Sobre la inembargabilidad de los bienes comunales, junto a los demaniales, vid. la STC 201/1998, de 14 de octubre (Pte.: Pablo García Manzano; FJ 2. ${ }^{\circ}$ ), que se apoya en la STC 
to a los bienes de dominio público, estableciendo que una ley será la que los regule.

Si bien es cierto que este artículo no establece claramente el carácter demanial de los bienes comunales, ello parece deducirse:

- Del hecho de que les atribuya un régimen jurídico similar al tener que inspirarse su regulación en los principios de inalienabilidad, imprescriptibilidad e inembargabilidad.

- De la referencia conjunta a bienes de dominio público y bienes comunales, en un intento por eliminar la confusión que anteriormente existía sobre si los bienes comunales eran patrimoniales o de dominio público $\mathrm{o}$, incluso, privados ${ }^{10}$.

Por su parte, la LBRL de 1985 se refiere en el artículo 80 a «los bienes comunales y demás bienes de dominio público...», indicándose con ese término «demás» el que además de los bienes de dominio público propiamente dichos hay otros bienes de dominio público, con un régimen más peculiar, que son los bienes comunales.

En apoyo de la demanialidad de los bienes comunales cabe citar el artículo 2.3 del RBEL de 1986, que los define claramente como de dominio público:

— «Tienen la consideración de comunales aquellos bienes que siendo de dominio público, su aprovechamiento corresponde al común de los vecinos.»

Las Comunidades Autónomas que regulan el régimen jurídico de los bienes de sus Entidades locales han establecido de forma clara la naturaleza demanial de los bienes comunales. Así, cuando definen los bienes de dominio público incluyen entre ellos a los bienes comunales, aunque los mismos van a tener un régimen jurídico peculiar que difiere, en parte, del régimen jurídico de los bienes de dominio público local afectos a un uso público o a un servicio público ${ }^{11}$.

\footnotetext{
168/1998, de 15 de julio (Pte.: J. D. González-Campos; FJ 12), que limita el privilegio de inembargabilidad.

${ }^{10}$ Claro que la referencia por separado a bienes de dominio público y comunales también puede interpretarse en el sentido de que tienen distinta naturaleza jurídica.

11 Así, La Ley 7/1987, de 15 de abril, de Régimen local de Cataluña, cuando en su artículo 185 define a los bienes de dominio público sostiene que «tendrán, también, esta consideración los bienes
} 


\section{Ahora bien, la admisión del carácter demanial de un bien comunal ha planteado tradicionalmente dos problemas referidos a los dos elementos determinantes para poder calificar un bien como de dominio público: \\ — La titularidad pública. \\ — La afectación.}

\section{Ello nos lleva a hacer un análisis de esta problemática y las distintas soluciones propuestas.}

comunales». Definiendo el artículo 186 a los bienes comunales como «aquellos cuyo aprovechamiento corresponda al común de los vecinos. Les será aplicable el régimen jurídico a los bienes de dominio público, sin perjuicio de las normas que regulen su aprovechamiento». El artículo 204 se refiere al régimen de aprovechamiento de estos bienes. La Ley 6/1990, de 2 de julio, de Administración local de Navarra, tras definir por separado los bienes de dominio público afectos a un uso público o a un servicio público, los bienes comunales cuyo aprovechamiento corresponde al común de los vecinos y los bienes patrimoniales (art. 98), establece en el artículo 99.2 que «los bienes comunales tienen la consideración de bienes de dominio público, y les será de aplicación lo establecido con carácter general en esta ley para los bienes de dicha naturaleza, en cuanto no esté previsto expresamente para aquella clase de bienes».

Purificación GonzÁlez Merchán, Comentarios a la Ley Foral de la Administración local de Navarra, dirigidos por Martín M. Razquin Lizarraga, Ángel Serrano Azcona, Gobierno de Navarra, Departamento de Administración Local, 1991, p. 308, sostiene: «De la dicción de este precepto no parece deducirse que los bienes comunales sean de dominio público, sino que, más bien, lo que se entiende es que, a efectos de aplicación de las notas de alienabilidad, inembargabilidad e imprescriptibilidad los bienes comunales se asemejan a los de dominio público».

El Capítulo II, del Título IV de la Ley Foral Navarra, regula el régimen aplicable a los bienes comunales en cuanto a su administración y actos de disposición, así como a su aprovechamiento. Dentro del aprovechamiento de los bienes comunales destacan los aprovechamientos de terrenos comunales de cultivo, de pastos comunales, aprovechamientos maderables y leñosos, de caza, etc.

- La Ley 7/1999, de 29 de septiembre, de Bienes de las Entidades Locales de Andalucía, establece que «Son bienes de dominio público los destinados a un uso o servicio público y los comunales. Tienen la consideración de comunales aquellos bienes cuyo aprovechamiento corresponde al común de los vecinos (art. 2.2). El Capítulo III, del Título II, se refiere al aprovechamiento de los bienes comunales. La Ley 7/1999, de 9 de abril, de Administración local de Aragón, establece que «son bienes de dominio público los destinados a un uso o servicio público, así como los comunales» (art. 170.1). «Tienen la consideración de comunales aquellos cuya utilización, aprovechamiento y disfrute corresponde al común de los vecinos» (art. 170.4). El artículo 183 regula el aprovechamiento de los bienes comunales y el artículo 180 su desafectación.

- La Ley 5/1997, de 22 de julio de Administración local de Galicia, define por separado los bienes de dominio público afectos a un uso o servicio público de los bienes comunales, estableciendo que estos últimos son «aquellos cuyo aprovechamiento corresponda a una comunidad vecinal por la normativa legal. Les será de aplicación el régimen jurídico que determine la ley, o en su defecto, el establecido para los bienes de dominio público [art. 263.2.b)]. Quizá en esta ley no se refleja una identificación tan clara entre bienes comunales y bienes de dominio público.

En definitiva, de la normativa autonómica parece deducirse que los bienes comunales son bienes de dominio público, pero dado que tienen una afectación peculiar, cual es el aprovechamiento por el común de los vecinos, tienen un régimen propio que regula fundamentalmente este aprovechamiento, y algunos otros aspectos de su régimen jurídico, pero en el resto les es plenamente aplicable el régimen de los bienes demaniales. 


\section{PROBLEMÁTICA EN TORNO A LA NATURALEZA DEMANIAL DE LOS BIENES COMUNALES}

Ya hemos adelantado que el problema que plantea la demanialidad de los bienes comunales hace referencia a cuál sea su verdadera titularidad y cuál su afectación.

\section{A. La titularidad o propiedad de los bienes comunales}

Diversas son las posturas sostenidas por la doctrina ${ }^{12}$ y la jurisprudencia del Tribunal Supremo ${ }^{13}$ respecto a la titularidad de los bienes comunales. Así, se ha sostenido:

\section{a) La titularidad exclusivamente vecinal}

En este sentido, la Sentencia del Tribunal Supremo de 14 de noviembre de $1995^{14}$ se apoya no sólo en el principio de jerarquía normativa que

\footnotetext{
12 Sobre las distintas posturas mantenidas en torno a la titularidad de los bienes comunales, vid. Juan A. Santamaría Pastor, Principios de Derecho Administrativo, v. II, Colección Ceura, Ed. Centro de Estudios Ramón Areces, S. A., Madrid, 1999, pp. 566-567.

${ }^{13}$ Hay que tener en cuenta que, cuando lo que se discute ante los Tribunales Contencioso-Administrativos es la declaración de un bien como comunal, el Tribunal Supremo tiene manifestado que, al tratarse de una cuestión de propiedad, dicho pronunciamiento corresponde a la Jurisdicción Civil; en tal sentido la STS de 3 de octubre del 2000 (Ar. 8449; Pte.: Antonio Martí García).

${ }_{14}$ En la Sentencia del TS de 14 de noviembre de 1995 (Ar. 8567. Pte.: Julián García Estartús), el Tribunal Supremo acepta los considerandos de la sentencia de la Sala de lo Contencioso Administrativo del Tribunal de Justicia de Navarra, según la cual las ordenanzas municipales para el aprovechamiento de pastos comunales no pueden excederse del marco previsto en la Ley Foral 6/1986, de 28 de mayo. Esta ley desarrolla el mandato constitucional del artículo 132.1 de regulación de una modalidad consuetudinaria de propiedad, en que la titularidad municipal es puramente formal, como modalidad específica de dominio público, siendo la titularidad real y material de los vecinos. La Ley foral concreta y define la especial naturaleza de los bienes comunales en Navarra, atribuyendo y reconociendo a los vecinos de los municipios derechos subjetivos de carácter patrimonial, que no pueden ser restringidos unilateralmente por los Estatutos municipales o su potestad normativa (FJ 1. ${ }^{\circ}$, de la sentencia apelada).
}

Así, califica la sentencia a los bienes comunales como una «categoría análoga al dominio público, que son, sin embargo, titularidad de los vecinos, y frente a los de propios (titularidad municipal) o a los de dominio público (afectación a un uso o servicio público), los bienes comunales están afectos al uso o aprovechamiento vecinal...». La Ley Foral define las modalidades de este aprovechamiento vecinal para que estén dirigidas primordialmente al cumplimiento de la función social de la propiedad (art. 33.2 CE) (FJ 2. ${ }^{\circ}$ de la sentencia apelada).

En el mismo sentido, el Tribunal Supremo expresa que la titularidad de los bienes comunales no corresponde a los Ayuntamientos, como se desprende del artículo 79.2 de la LBRL, que establece que «los bienes de los entes locales son de dominio público o patrimoniales», sin incluir en la titula- 
impide que un reglamento, en el caso una Ordenanza municipal, contradiga lo dispuesto en una ley, concretamente en una ley foral de Navarra que desarrolla el mandato del artículo 132.1 de la CE de que una «ley regulará el régimen jurídico ... de los bienes comunales», sino también en la negación de la titularidad municipal sobre los bienes comunales, para sostener la invalidez de la Ordenanza del Ayuntamiento de Tudela sobre aprovechamiento de pastos, que exige condiciones no previstas en la Ley Foral de Navarra sobre bienes comunales de 1986 para poder participar en el concurso relativo al aprovechamiento de pastos.

Así, se sostiene que los bienes comunales, a pesar de ser una categoría análoga a los bienes de dominio público, son, sin embargo, titularidad de los vecinos. Para negar la demanialidad de los bienes comunales y, consecuentemente, su titularidad municipal se apoya:

- En que los bienes comunales, a diferencia de los bienes de dominio público, en los que la titularidad es municipal, no están afectos a un uso o servicio público, sino al uso o aprovechamiento vecinal. Así pues, es la afectación un elemento tenido en cuenta para negar la titularidad municipal de los bienes comunales.

— En el artículo 79.2 de la LBRL, que establece que «los bienes de los entes locales son de dominio público o patrimoniales», sin incluir en la titularidad de las Entidades locales los comunales.

Esta sentencia puede ser objeto de crítica desde varios puntos de vista:

- No cabe considerar a los bienes comunales como una categoría «análoga» al dominio público, y a la vez afirmar que son de titularidad exclusivamente vecinal, pero destinados a la consecución de un destino público que pretende el cumplimiento de la función social de la propiedad (art. 33.2 CE), dado que estas características hacen calificar su naturaleza jurídica como de bienes privados.

Claro que el hecho de que el régimen jurídico de los bienes comunales se aproxime más a los bienes de dominio público que a los privados lleva al Tribunal a apreciar esa analogía entre bienes demaniales y comunales ${ }^{15}$.

\footnotetext{
ridad de las entidades locales los comunales, sin perjuicio, de definir su naturaleza como bienes de dominio público y ser inalienables, imprescriptibles e inembargables (art. 80.1 LBRL), en cumplimiento de lo que dispone el artículo 132.1 CE (FJ 3. $\left.{ }^{\circ}\right)$.

${ }^{15}$ El problema se encuentra en los elementos a que debemos atenernos para definir un bien como demanial, y parece admitido por la doctrina mayoritaria que los mismos deben ser la titularidad ad-
} 
- Sostener, como hace el Tribunal Supremo, que los bienes comunales no son de titularidad del Ayuntamiento porque el artículo 79.2 LBRL no los incluye entre los bienes demaniales, y afirmar a renglón seguido que «esa normativa define la naturaleza de los bienes comunales como bienes de dominio público» merece dos objeciones:

- El artículo 79.2 de la LBRL clasifica los bienes de las Entidades Locales en bienes de dominio público y patrimoniales, porque entre los primeros se incluyen los bienes comunales, como se deduce de que el párrafo $3 .^{\circ}$ de ese mismo artículo se refiera a los bienes de uso público, de servicio público y comunales, queriendo indicar que se diferencian por las distintas afectaciones.

- No cabe mantener que la LBRL define la naturaleza de los bienes comunales como bienes de dominio público y, a la vez, afirmar que los mismos son de titularidad vecinal, no del Ayuntamiento, dado que la naturaleza demanial de un bien entraña su titularidad administrativa, no privada.

La titularidad vecinal o privada de los bienes comunales, pero reservándose la gestión de los mismos el municipio, es puesta de manifiesto también por el Consejo de Estado en su Dictamen de 22 de junio de 1995. Así, se sostiene que: «La titularidad de estos aprovechamientos, ganaderos, corresponde a los vecinos..., constituyen una forma de propiedad comunal cuya titularidad no es administrativa, y cuya gestión corresponde a las Corporaciones locales en la medida en que son precisamente los vecinos, por su condición de tales, los propietarios del terreno en cuestión» ${ }^{16}$.

La titularidad exclusivamente vecinal de los bienes comunales supone confundir al titular del bien con el titular del aprovechamiento ${ }^{17}$. El hecho de que la normativa reguladora de los bienes comunales los defina en orden a su característico aprovechamiento vecinal, a su afectación, ha llevado a confundir la afectación con la titularidad del bien.

A ello debemos unir que en ningún momento la normativa reguladora de este tipo de bienes afirma la titularidad vecinal de los mismos, cuando,

ministrativa y la afectación a un destino público. Dándose esos dos elementos integramos a un bien en el régimen jurídico exorbitante de protección de los bienes demaniales. No parece, así, correcto analizar el régimen jurídico del bien para determinar su naturaleza demanial o análoga, ya que deben previamente darse esos dos elementos: titularidad administrativa y afectación pública.

${ }^{16}$ Dictamen n. ${ }^{\circ}$ 944/95, de 22 de junio, apdo. IV. Consejo de Estado. Recopilación de la Doctrina legal, 1995.

17 Sobre los requisitos de vinculación vecinal para ser beneficiario de los aprovechamientos de los bienes comunales, vid. STC 308/1994, de 21 de noviembre (Pte.: A. Rodríguez Bereijo, FJ 2, 3 y 4 ). 
por el contrario, sí que encontramos alguna muestra de afirmación de la titularidad administrativa de estos bienes ${ }^{18}$. Además, cuando el legislador ha querido atribuir la titularidad vecinal respecto de ciertos bienes (v. gr., montes vecinales en mano común) lo ha hecho expresamente ${ }^{19}$.

\section{b) La titularidad compartida de los bienes comunales}

Un importante sector doctrinal y abundante jurisprudencia del Tribunal Supremo viene afirmando la titularidad compartida entre el municipio y los vecinos de los bienes comunales. De esta forma, al Ente local corresponderían las facultades de administración y conservación del bien y a los vecinos las facultades de aprovechamiento ${ }^{20}$.

\section{c) La titularidad municipal de los bienes comunales}

De la regulación actual de los bienes comunales puede deducirse el carácter de bienes demaniales que poseen $\mathrm{y}$, en consecuencia, su titularidad administrativa, fundamentalmente municipal ${ }^{21}$.

18 Artículo 2.4 del RBEL: «Los bienes comunales sólo podrán pertenecer a los municipios y a las Entidades Locales menores».

19 Artículo 83 LBRL'85 y Ley 55/1980, de 11 de noviembre, de Montes vecinales en mano común.

20 Vid., en este sentido, A. Nieto García, Bienes comunales, op. cit., pp. 269-271; «La nueva regulación de los bienes...», op. cit., p. 13. F. SAINZ Moreno, «Los bienes de las Entidades...», op. cit., pp. 1594-1596; sostiene este autor que aunque el artículo 2.4 del RBEL establezca que «los bienes comunales sólo pueden pertenecer a los municipios o a las Entidades Locales menores», la titularidad de estos bienes no es exclusivamente municipal, ya que se admite una propiedad compartida entre el municipio y los vecinos de naturaleza jurídico-administrativa; en el mismo sentido se pronuncia el autor en Comentarios a la Constitución Española de 1978, dirigidos por Óscar Alzaga, op. cit., p. 240. A. Guaita, Derecho Administrativo. Aguas..., op. cit., pp. 283-284. L. Morell OCAÑa, Curso de Derecho Administrativo, tomo I. Derecho Administrativo y sus fuentes. La organización administrativa y sus medios. Ed. Aranzadi, 1998, p. 582.

Por su parte, a la titularidad compartida de los bienes comunales se refiere el Tribunal Supremo en gran número de sentencias. Sirvan de muestra: la Sentencia de 28 de octubre de 1975 (Ar. 4186; Pte.: Paulino Martín Martín); la Sentencia de 8 de noviembre de 1977 (Ar. 4159; Pte.: P. Martín de Hijas y Muñoz, FJ $4 .{ }^{\circ}$ de la sentencia apelada, aceptado por el Tribunal Supremo), cuando todavía los bienes comunales se consideraban como bienes patrimoniales por su regulación en la Ley de Régimen Local de 1955 y su Reglamento de Bienes. La Sentencia de 15 de marzo de 1980 (Ar. 1800; Pte.: P. Martín Martín; Cdo. 3. ${ }^{\circ}$ ); la Sentencia de 18 de mayo de 1982 (Ar. 3964; Pte.: P. Martín Martín; cdo. $\left.4 .^{\circ}\right)$.

${ }^{21}$ F. SAinz Moreno, «Los bienes de las Entidades...», op. cit., p. 1596, excluye la posibilidad de bienes comunales de titularidad provincial o estatal, basándose en la dicción literal del artículo 2.4 del RBEL, que atribuye la titularidad de los mismos en exclusiva a los municipios y entidades locales menores. 
Si bien es cierto que ni la CE en su artículo132.1 atribuye la titularidad de los bienes comunales a los municipios (ni siquiera les atribuye claramente el carácter de demanial), ni tampoco lo hacen los artículos 79.2 y 80 de la LBRL, los mismos pueden interpretarse en el sentido de que los bienes comunales son de dominio público. Así:

- La CE contiene una referencia expresa a los mismos junto a los bienes de dominio público, precisamente para aclarar su régimen jurídico, y para evitar que su no expresa referencia diera lugar a nuevos conflictos sobre su naturaleza jurídica.

- El artículo 79.3 de la LBRL establece que son bienes de dominio público los destinados a un uso o servicio público, para a continuación definir la afectación de los bienes comunales. Parece, pues, que este apartado está definiendo los bienes de dominio público, que se diferencian por su afectación a un uso público, a un servicio público o al aprovechamiento vecinal (comunales) ${ }^{22}$.

- De la redacción del artículo 80 de la LBRL: «bienes comunales y demás bienes de dominio público...», parece deducirse ese carácter demanial.

Ahora bien, si puede plantearse alguna duda interpretativa en el análisis de la legislación básica reguladora de los bienes comunales, la misma se disipa totalmente si analizamos la legislación de bienes locales de las Comunidades Autónomas con regulación en la materia. Así, de la normativa autonómica, ya analizada, se deduce la expresa consideración demanial de los bienes comunales; ello, sin perjuicio de que ciertos aspectos de los mismos, como su utilización, participen de un régimen jurídico propio, distinto del resto de los bienes de dominio público local (afectos a un uso público o a un servicio público).

Por otro lado, si de la normativa básica estatal no resulta claramente establecida la naturaleza demanial de los bienes comunales, no ocurre lo mismo si analizamos el Reglamento de Bienes de las Entidades Locales de 1986, que desarrolla esa normativa y que tiene mero carácter supletorio de la regulación autonómica en la materia ${ }^{23}$. Así, el artículo 2.4 del

${ }^{22}$ Vid. esta misma interpretación en J. Luis Rivero Ysern, Manual de Derecho Local, 4. ${ }^{a}$ ed., Ed. Civitas, S. A., 1999, p. 288.

${ }^{23}$ No existe unanimidad en la doctrina respecto al lugar que corresponde al RBEL en el sistema de fuentes normativas. Así, hay autores que sostienen su carácter básico, mientras que para otros tiene mero valor supletorio.

En este sentido, Alegre Ávila sostiene «la vigencia plena y directa en todas las Comunidades Autónomas, incluidas aquellas que poseen competencias de carácter legislativo en este ámbito (bienes 


\section{RBEL de 1986 establece que «los bienes comunales sólo podrán pertene-} cer a los municipios o a las entidades locales menores ${ }^{24 » .}$

El tratar de interpretar el artículo 2.4 del RBEL alegando que el término «pertenecer» no significa lo mismo que propiedad, sino que hace alusión a las potestades o facultades que sobre determinados bienes corresponderían a una determinada Administración, como hace un sector doctrinal ${ }^{25}$ con la intención de mantener la titularidad compartida (muni-

de las entidades locales, comunales), de la práctica totalidad de los preceptos del Reglamento de Bienes de las Entidades Locales de 13 de junio de 1986, como garantía de una unidad básica del ordenamiento jurídico de los bienes locales en todo el territorio nacional, por un lado, $\mathrm{y}$, por otro, como corolario del estrecho margen que, en este punto, debe concederse a la normativa autonómica por no verse directamente implicadas exigencias de una política legislativa propia y diferenciada», en «El nuevo sistema de fuentes de los bienes locales, con particular referencia a los bienes comunales», REALA, n. ${ }^{\circ} 231$ (1986-1987; p. 515).

Por el contrario, F. SAINZ MoRENo, «Los bienes de las Entidades...», op. cit., p. 1592, apoyándose en el artículo 5 de la LBRL (artículo declarado inconstitucional por la STC 214/1989, de 21 de diciembre, debido a su carácter interpretativo, y actualmente con un nuevo contenido a raíz de la Ley 11/1999, de 21 de abril), considera como supletorio el RBEL en cuanto a la normativa autonómica que recoge el régimen jurídico de los bienes de las Entidades Locales.

Martínez Vares García, al referirse a la legislación básica del Estado sobre régimen local, incluye a la LBRL y al TRRL (en los artículos que cita la DF 1. a), pero no, así, al RBEL, en «Los bienes de las Entidades Locales», en Cuadernos de Derecho Judicial, Administración Local. CGPJ. Madrid, 1995; p. 426.

BERMEJO VERA sostiene que «hasta la presente aprobación de las leyes autonómicas sobre patrimonio, el RBEL era la norma básica y fundamental para el estudio de las propiedades públicas en nuestro ordenamiento jurídico», en Derecho Administrativo. Parte Especial, Ed. Civitas, S. A., 1998, p. 313. De lo que se deduce que con la aprobación de esa legislación autonómica, ésta prima sobre lo establecido en el RBEL, con lo cual éste no tiene carácter básico.

También Ballester Marquina, Martínez Pallarés y otros: Manual básico de Administración..., op. cit., p. 50, reconocen el carácter de normativa no básica al RBEL.

${ }^{24}$ Respecto a la recuperación de oficio de la posesión de una finca que venía siendo destinada a aprovechamiento comunal para pastos por una Entidad local menor, vid. la STS de 4 de diciembre de 1997 (Ar. 9359; Pte.: Mariano Baena del Alcázar).

25 En este sentido, Nieto García: «La nueva regulación de los bienes...», op. cit. (pp. 14-15), cita autores civilistas, que comentando el Código Civil, concretamente los artículos que se refieren a que ciertos bienes «pertenecen» al Estado, como el artículo 339, han negado la relación de propiedad basándose, como MANRESA en que pertenencia y propiedad no significan lo mismo, sino que la noción pertenecer es mucho más amplia que la de propiedad en sentido jurídico positivo que del Derecho romano se deriva, afirmando este autor que «la relación jurídica que mantiene el Estado con estos bienes de dominio público no es una relación de propiedad, sino de pertenencia, que trae como consecuencia ciertas prerrogativas jurídicas a favor del Estado como soberano territorial... Es una verdadera función de policía social y administrativa, ya de seguridad ya de servicio general. El Estado tiene bajo su acción soberana todos estos bienes; para que respondan a un fin de interés general, los cuida, los conserva y regula, cuando es preciso, el uso de los mismos». Concluye el autor haciéndose eco de que la legislación vigente deja las cosas como estaban, ya que no utiliza el término propiedad en lo que se refiere a los bienes de dominio público y comunales, sino que sigue utilizando el término «pertenecer» en el artículo 79.1 de la LBRL y artículo 2.3 del Reglamento de Bie- 
cipal y vecinal) de los bienes comunales, parece ir más allá de la verdadera finalidad o espíritu de la norma.

Si partimos de la consideración del dominio público como una relación de propiedad, según la cual un bien participa de esta naturaleza cuando es de titularidad de una Administración y está afecto a un destino público, podemos concluir que la titularidad de los bienes comunales corresponde al Ente local correspondiente, normalmente, el municipio.

En este sentido, si bien la legislación básica de régimen local no determina de forma clara la titularidad de los bienes comunales, como tampoco lo hace la legislación autonómica en la materia, la misma puede deducirse:

— No sólo del carácter demanial de los mismos,

- sino, también, del hecho de que la desafectación de los bienes comunales se realice por la Entidad local correspondiente ${ }^{26}$.

También un sector doctrinal y la jurisprudencia del Tribunal Supremo ha sostenido la titularidad municipal de los bienes comunales ${ }^{27}$.

nes de las entidades locales; sólo del artículo 8.4.c) del Reglamento de Bienes parece deducirse, según el autor, que se refiere a la propiedad cuando alude a la posibilidad de adquirir el «dominio» por usucapión.

Esta interpretación de que se hace eco el autor trata de fundamentar el hecho de que los bienes comunales, aunque la normativa local diga que «pertenecen a los municipios...», su propiedad es compartida entre los municipios y los vecinos.

${ }^{26}$ El artículo 78.1 del TRRL'86 establece que la desafectación de los bienes comunales será acordada por la Entidad Local respectiva. El artículo 189 de la Ley de Administración Local de Cataluña de 1987 alude a la necesidad de acuerdo «del pleno» para tal desafectación, lo que implica la titularidad municipal de los bienes comunales; en el mismo sentido, se pronuncia el artículo 6 de la Ley de Bienes de las Entidades Locales de Andalucía.

El artículo 139 de la Ley de Administración Local de Navarra de 1990 establece que las facultades de disposición, administración, régimen de aprovechamiento y ordenación de los bienes comunales corresponden a las Entidades Locales en los términos de esta ley foral. Solamente en casos previstos expresamente en esta ley necesitarán de la aprobación por la Administración de la Comunidad Foral las decisiones acordadas por los órganos competentes de las Entidades Locales.

El artículo 180 de la Ley de Administración local de Aragón prevé que el acuerdo de la Entidad Local para la desafectación de un bien será aprobado definitivamente por la Comunidad Autónoma.

En definitiva, la disposición y ordenación que de los bienes comunales pueden hacer los Entes locales da muestra de la titularidad local de los mismos.

${ }^{27}$ En tal sentido, vid. J. Bermejo Vera, Derecho Administrativo..., op. cit., p. 315, sostiene la titularidad municipal de los bienes comunales. J. Migallón Rubert, Manual de Derecho..., op. cit., p. 316, sostiene que los bienes comunales sólo podrán pertenecer a los municipios y a las Entidades 


\section{B. La afectación peculiar de los bienes comunales}

Como se desprende del artículo 79.3 de la LBRL y del artículo 2.3 del RBEL ${ }^{28}$, la afectación de los bienes comunales es el aprovechamiento y disfrute por los vecinos sobre estos bienes. En este sentido se manifiesta unánimemente la doctrina ${ }^{29}$.

Así pues, la normativa reguladora de los bienes comunales se inclina por considerarlos como bienes de dominio público, pero lo hace por mor de una afectación o destino público, que diverge del de la mayoría de los

Locales menores. F. J. FeRnÁndez GonZÁLEZ y otros, Lecciones de dominio público, Ed. Colex, Madrid, 1999, p. 102, mantiene que la titularidad de los bienes comunales corresponde a las Entidades Locales.

Por otra parte, una muestra jurisprudencial del reconocimiento de la titularidad o propiedad municipal de los bienes comunales la tenemos en la Sentencia de 31 de diciembre de 1986 (Ar. 1696; Pte.: M. Gordillo García), donde tras recoger la definición que la anterior normativa reguladora de los bienes locales contenía de los mismos, como los de dominio municipal, cuyo aprovechamiento y disfrute pertenece exclusivamente a los vecinos (art. $187 \mathrm{LRL}$ ), viene a sostener (cdo. $3 .^{\circ}$ de la sentencia apelada, aceptado por el Tribunal Supremo) que «en tal condición son los entes locales los que regulan su disfrute, por ser titulares del derecho patrimonial y pertenecerles los derechos administrativos derivados del mismo en su condición de representantes legales de la comunidad; los vecinos disfrutan los bienes en nombre del Ayuntamiento como propietario, y los poseen al modo en que lo hace un arrendatario o precarista en nombre del titular; y como no pueden ser poseídos a título de dominio, los actos que puedan ejercitar sobre ellos son de simple disfrute...». En el mismo sentido, la Sentencia de 30 de abril de 1987 (Ar. 4768; Pte.: J. García Estartús, cdo. 3. ${ }^{\circ}$ de la sentencia apelada); Sentencia de 24 de enero de 1989 (Ar. 430; Pte.: A. Bruguera Mante, cdo. 3. ${ }^{\circ}$ de la sentencia apelada).

Aplicando ya la normativa de régimen local estatal vigente, la Sentencia de 3 de mayo de 1989 (Ar. 3641; Pte.: F. González Navarro) viene a sostener la titularidad municipal de los bienes comunales al afirmar que no se pueden desconocer las facultades que en orden a la administración y mejor disfrute de los bienes comunales pueden establecer los Ayuntamientos en «cuanto titulares de los mismos y, por ello, con plenas facultades de administración» (FJ 4. ${ }^{\circ}$ de la sentencia apelada, que acepta el Tribunal Supremo).

${ }^{28}$ El artículo 79.3 LBRL establece que «... tienen la consideración de comunales aquellos cuyo aprovechamiento corresponda al común de los vecinos». El artículo 2.3 del RBEL establece que «tienen la consideración de comunales aquellos bienes que, siendo de dominio público, su aprovechamiento corresponde al común de los vecinos».

29 Juan M. Alegre Ávila, «El nuevo sistema de fuentes de los bienes locales...», op. cit., p. 512. A. Nieto García, Bienes comunales, op. cit., pp. 286 a 288 y 289. Este autor, junto a la titularidad de los bienes comunales, analiza el tema de la afectación o destino de los mismos, estableciendo que:

- Respecto a los vecinos, éstos van a disfrutar de un derecho real administrativo de goce, derecho que va a derivar de la vecindad o condición de vecino.

- Mientras que al municipio le corresponderían las facultades de «administración, conservación y rescate de su patrimonio, la defensa del forestal contra todos los ataques a su integridad, en su suelo y en el vuelo...». 
bienes de las Entidades locales (el uso o servicio público), cual es su destino a ser aprovechado por el común de los vecinos ${ }^{30}$. Se excluye de esta forma una utilización indistinta por todos los ciudadanos, limitándola a los exclusivamente vecinos del Ente local.

Es, pues, un destino o afectación digno de protección por el legislador, máxime cuando el artículo 132.1 de la CE se refiere expresamente a esta categoría de bienes.

La Sentencia del Tribunal Supremo de 14 de noviembre de $1995^{31}$ considera a los bienes comunales como una categoría «análoga» al dominio público, pero propiamente como bienes vecinales, no sólo por la titularidad vecinal de estos bienes, sino también por su afectación. Así, mientras que los bienes de dominio público se encuentran destinados a un uso o servicio público, los bienes comunales están afectos al uso o aprovechamiento vecinal. Aprovechamiento vecinal que se encuentra primordialmente dirigido al cumplimiento de la función social de la propiedad (art. 33.2 CE).

Consideramos que, al igual que se reconoce la afectación de los bienes demaniales a un uso o servicio público, debe admitirse la afectación a un aprovechamiento vecinal, en la medida en que históricamente así se ha reconocido para los llamados bienes comunales. En consecuencia, los comunales no constituyen una categoría «análoga» al dominio público, sino propiamente dominio público; lo que ocurre es que, al igual que el régimen de aprovechamiento de los bienes demaniales de uso público diverge del de los de servicio público, también los bienes comunales tienen un régimen jurídico de aprovechamiento peculiar.

\section{PROTOTIPO DE BIEN COMUNAL: LOS MONTES MUNICIPALES}

Por la importancia que dentro de los bienes comunales ostentan los montes ${ }^{32}$, podemos considerarlos como su prototipo.

\footnotetext{
${ }^{30}$ El conjunto de personas inscritas en el Padrón Municipal conforman los vecinos del municipio, según el artículo 15 de la LBRL'85.

${ }^{31}$ Sentencia de 14 de noviembre de 1995 (Ar. 8567; Pte.: Julián García Estatús; FJ 2. ํ de la sentencia apelada, aceptado por el Tribunal Supremo).

32 F. Sainz Moreno, «Bienes de las Entidades Locales»..., op. cit., p. 1595; A. Guaita, Derecho Administrativo. Aguas..., op. cit., pp. 279-280, también, manifiesta que la mayoría de los bienes comunales son montes.
} 
Sin embargo, no todos los montes son bienes comunales, sino que por su titularidad pueden ser públicos o privados ${ }^{33}$, según que su titularidad corresponda a una Administración pública (Estado, Comunidades Autónomas y Entidades Locales), o a particulares, respectivamente; y, según su régimen jurídico, pueden ser patrimoniales, demaniales o comunales ${ }^{34}$.

Vamos a centrarnos en los montes de titularidad del municipio o Entidades Locales Menores, analizando su clasificación y la necesidad de realizar un aprovechamiento más rentable de los mismos.

\section{A. Clasificación}

Los montes de propiedad pública se clasifican por la doctrina ${ }^{35}$ en bienes patrimoniales o de propios, demaniales o comunales. Por consiguiente, los montes municipales se clasifican en:

\section{a) Los montes de propios}

A los montes de propios se refiere el TRRL'86 cuando establece que «las Entidades locales tendrán la facultad de explotar los montes de su propiedad, así como su conservación y fomento, en el marco de lo establecido por la legislación específica de montes» (art. 84.1). También el RBEL'86, en su artículo 107, se refiere a los montes patrimoniales al recoger el derecho de tanteo de las Corporaciones locales en las subastas de pastos sobrantes de dehesas boyales y montes comunales y patrimoniales.

33 R. Parada Vázquez, Derecho Administrativo III. Bienes públicos y Derecho Urbanístico, Ed. Marcial Pons. 2000, pp. 217-218, considera que los montes particulares constituyen una propiedad privada especial, dada la fuerte intervención administrativa a que se sujetan. En el mismo sentido, vid. M. ${ }^{a}$ del Rosario Alonso IBÁÑEz, Lecciones de dominio público, Ed. Colex, Madrid, 1999, pp. 237-238.

Esta fuerte intervención administrativa tiene sentido cuando la gran mayoría de la propiedad forestal es privada, según manifiesta J. M. ABReu y Pidal, Propiedad, titularidad y funcionalidad de los terrenos forestales, Ministerio de Agricultura, Pesca y Alimentación. Madrid. 1995, p. 26.

34 Respecto a esta clasificación de los montes, vid. J. Bermejo VERA, Derecho Administrativo, op. cit., p. 479; M. ${ }^{\mathrm{a}}$ Bellido BARrionuevo y otros: Derecho Administrativo..., op. cit., p. 549; A. Guaita, Derecho Administrativo. Aguas..., op. cit., p. 219 y ss.; J. M. a de la CuÉTARA, La actividad de la Administración..., op. cit., p. 396 y ss.; J. M. A ABReu y PidAl, Propiedad, titularidad..., op. cit., pp. 80 y ss.

35 Bermejo Vera sostiene que, «según su régimen jurídico, los montes públicos pueden encontrarse en cualquiera de las figuras existentes dentro de las denominadas propiedades públicas (demaniales, patrimoniales y comunales); vid. Derecho Administrativo..., op. cit., p. 479. 
Los montes de propios han sido definidos por la doctrina ${ }^{36}$ como aquellos que, siendo propiedad de un municipio o de la provincia, no están destinados a la realización de ningún servicio, y pueden constituir fuente de ingresos para los erarios municipal o provincial.

Los bienes de propios han sido tradicionalmente definidos por la jurisprudencia del Tribunal Supremo como aquellos que pueden constituir renta para el municipio ${ }^{37}$.

En consecuencia, estos bienes, montes de propios, no son bienes demaniales, sino patrimoniales.

\section{b) Los montes demaniales}

Con carácter general se admite que son montes demaniales municipales los afectos a un uso o servicio público.

En este sentido, la doctrina ${ }^{38}$ ha considerado como montes demaniales por su afectación a un uso público un monte destinado a una escuela de montes para la investigación y la enseñanza o a parque.

Sin embargo, la normativa estatal reguladora de los bienes de las Entidades Locales no incluye directamente entre los bienes de uso público a los montes, aunque sí incluye expresa referencia a los parques ${ }^{39}$, como

${ }^{36}$ En este sentido, Alonso Moya, «Sobre las aguas de dominio público y de dominio privado», $R A P$ n. $^{\circ} 4,1951$, p. $58-59$.

Por su parte, Rafael Altamira y Crevea, Historia de la propiedad comunal, IEAL, Madrid, 1981. Col. Administración y Ciudadano, n. ${ }^{\circ} 15$, p. 355 , los define como «aquellos bienes cuyo dominio y aprovechamiento corresponde a los municipios como personas jurídicas, pero sin participación individual de sus miembros». Para A. Nieto García, «Bienes comunales: refundición del dominio forestal de suelo y vuelo», RAP n. ${ }^{\circ} 60$ (1969, p. 130), junto a los montes comunales y los de propiedad colectiva del común de los vecinos, se encuentran los «de propiedad individual» de los municipios. GARCÍA DE ENTERRÍA, Las formas comunitarias de propiedad forestal..., op. cit., p. 16, manifiesta que la distinción entre bienes de propios y bienes comunales se «articula sobre la consideración de los primeros como una propiedad del Ayuntamiento como ente independiente, con lo que se volatiliza, por consiguiente, la vieja titularidad colectiva de los vecinos. Se trata de bienes que éstos, los vecinos, no utilizan en propio beneficio...».

37 En este sentido, Eloy Colón Piazuelo, «Algunas reflexiones en torno a los bienes comunales», REALA n. ${ }^{\circ} 237$ (1988, p. 863 y ss.).

38 En este sentido, vid. R. PARAda VÁzquez, Derecho Administrativo..., op. cit., p. 217; M. ${ }^{\text {a del Ro- }}$ sario Alonso Ibáñez, Leciones de dominio público, op. cit., p. 222; A. Guatta, Derecho Administrativo. Aguas..., op. cit., p. 32, aclara este autor que un monte debe ser terreno rústico, por lo que no tienen tal consideración los parques y jardines municipales (p. 218).

${ }^{39}$ En este sentido, el artículo 74.1 del TRRL'86, en la enumeración ejemplificativa que contiene de los bienes de dominio público local afectos a un uso público, incluye a los parques, entre los que po- 
tampoco lo hace la normativa autonómica en la materia, que normalmente no contiene una relación ejemplificativa de los bienes demaniales locales, salvo algunas excepciones, como la legislación de Administración local de Galicia o de Aragón ${ }^{40}$.

La jurisprudencia del Tribunal Supremo recoge algunos supuestos en que un monte se califica como demanial por su afectación a un uso público. En concreto por haber quedado constituido como zona verde tras un Plan de urbanismo.

Tal es el caso recogido en la Sentencia de 30 de octubre de $1978{ }^{41}$, en la cual se discute la naturaleza jurídica de un terreno enclavado en un monte, bien de propios del Ayuntamiento de San Martín de Valdeiglesias (Madrid), que fue cedido por éste a un particular para su explotación industrial.

En la medida en que dichos terrenos del monte de propios se cedieron por el Ayuntamiento a una empresa privada para la realización de un plan de promoción turística, que una vez ejecutado otorgaron a los terrenos el carácter de bienes de dominio público, el Ayuntamiento pretende el desahucio del particular que venía explotando industrialmente los mismos. Así, la sentencia apelada confirma la titularidad del Ayuntamiento sobre los terrenos del monte que como consecuencia del plan de urbanización quedaron constituidos como zona verde o espacio libre, en consecuencia, como un bien de dominio y uso público. En base a ello se declara proceder el desahucio por cumplimiento del plazo otorgado en la autorización para explotación industrial de dichos terrenos.

Los montes, como bienes de dominio público, se recogen en la normativa estatal reguladora de los bienes locales cuando enumera los bienes afectados a un servicio público ${ }^{42}$. Sin embargo, mientras que el TRRL'86 sólo considera como bienes de dominio público los montes ca-

demos incluir los propiamente urbanos y aquellos que tengan naturaleza rústica. El mismo pronunciamiento lo encontramos en el artículo 3.1 del RBEL'86.

${ }^{40}$ La Ley 5/1997, de 22 de julio, de Administración Local de Galicia, recoge una ejemplificación de los bienes locales de uso público en su artículo 264, incluyendo entre los mismos a los parques.

También la Ley 7/1999, de 9 de abril, de Administración Local de Aragón, enumera los bienes locales de uso público, incluyendo entre ellos los parques (art. 170.2).

${ }^{41}$ Sentencia de 30 de octubre de 1978 (Ar. 3991; Pte.: Félix Fernández Tejedor).

${ }^{42}$ El artículo 74.2 del TRRL'86 sostiene que «son bienes de servicio público los destinados al cumplimiento de fines públicos..., así como los montes catalogados de propiedad provincial».

Por su parte, el artículo 4 del RBEL'86 incluye como bienes de servicio público local los montes catalogados, sin añadir referencia a cuál deba ser su titularidad. 
talogados de propiedad provincial, el RBEL'86 no establece cuál deba ser su titularidad. Por su parte, la única Comunidad Autónoma que recoge los montes catalogados como bienes demaniales por afectación a un servicio público, Galicia ${ }^{43}$, tampoco exige que sean de titularidad provincial. De ello, podríamos deducir que, tratándose de montes catalogados de titularidad municipal, los mismos pueden considerarse demaniales por su afectación a un servicio público.

La doctrina se encuentra dividida entre quienes niegan a los montes su posible destino a un servicio público ${ }^{44}$, quienes lo admiten, pero sólo respecto de los montes catalogados de propiedad provincial ${ }^{45}$ y quienes admiten que los montes catalogados sean dominio público, lo que puede suceder por prescripción legal expresa o por afectación concreta a un uso público (v. gr., Parques Nacionales) o, al fomento de la riqueza, o sea, aquellos de una utilidad pública suficientemente intensa como para entender que esta afectación se ha producido ${ }^{46}$.

\section{c) Los montes comunales}

Consideramos que los montes comunales típicos, como el resto de los bienes comunales, pueden considerarse como bienes demaniales municipales cuando su titularidad corresponda a un municipio, según hemos deducido de la normativa reguladora de los bienes comunales. La única diferencia con los montes demaniales típicos, o sea, aquellos cuya afectación es a un uso o servicio público, radica precisamente en su peculiar afectación o destino a un «aprovechamiento vecinal», lo que les hace sujetarse a un régimen jurídico peculiar, sobre todo en cuanto a su forma de utilización.

Este régimen jurídico peculiar hace que los tratemos de forma independiente de los bienes demaniales, pero afirmando previamente su naturaleza demanial.

\footnotetext{
43 En este sentido, la Ley 5/1997, de 22 de julio, de Administración Local de Galicia (art. 265).

44 A. Guaita, Derecho Administrativo. Aguas..., op. cit., p. 32.

45 J. M. a Abreu y Pidal, Propiedad, titularidad..., op. cit., p. 84, sostiene que no cabe calificar de demaniales los montes municipales en la medida en que el RBEL'86 extiende o amplía la regulación contenida en el TRRL'86, que es una norma de rango superior.

46 J. M. De la CuÉtara, La actividad de la..., op. cit., p. 398. Para este autor los montes catalogados pueden ser simplemente patrimoniales (pp. 398-399).
} 
Así, los montes comunales se integran dentro de la categoría de los bienes comunales, a los que tradicionalmente se les atribuye su dominio al municipio y su aprovechamiento a los vecinos ${ }^{47}$.

La mayoría de la doctrina ${ }^{48}$ diferencia dentro de los montes comunales dos tipos, los

- Típicos, o sea, los regulados por la LBRL de 1985, cuya titularidad se atribuye a los municipios y el aprovechamiento al común de los vecinos.

- Atípicos: aquellos cuya regulación corresponde a leyes especiales o a la costumbre, y dentro de los cuales destacan los montes vecinales en mano común ${ }^{49}$.

\footnotetext{
${ }^{47}$ Así lo manifiesta Altamira y Crevea, Historia de la propiedad..., op. cit., p. 355, quien los define como «aquellos que, descansando perpetuamente en el dominio de la Corporación, son gozados y disfrutados sucesiva y singularmente por todos los individuos o familias, que de generación en generación componen el cuerpo de habitantes».
}

Por su parte, GARCía de ENTERRíA, Las formas comunitarias..., op. cit., p. 51, cuando trata de diferenciar los montes vecinales de los comunales expresa que «sólo estos últimos son bienes de las Entidades Locales (arts. 79.2 de la LBRL y 75 del TRRL)»; con lo que se decanta por la titularidad municipal de los montes comunales. También se refiere el autor a la titularidad municipal de los montes comunales típicos cuando los diferencia de los bienes patrimoniales (vid. Las formas comunitarias..., op. cit., p. 18). Así, establece que: «frente al caso de los bienes de propios, en los bienes comunales se sustantiva el dato del directo aprovechamiento colectivo o comunal por parte de los vecinos, en su individualidad...». J. M. ${ }^{\text {a }}$ DE ABREU y PidAL, Propiedad, titularidad..., op. cit., pp. 89 y ss.

48 Así, F. Sainz Moreno, «Los bienes de las Entidades...», op. cit., pp. 1595 y 1596, distingue los bienes comunales en típicos y atípicos.

También el profesor NiETo García se refiere junto a los bienes comunales típicos a los comunales atípicos, incluyendo entre estos últimos a los montes vecinales, en «La Ley de montes vecinales en mano común de 27 de julio de $1968 », R A P$ n. ${ }^{\circ} 57$ (1968, p. 351).

49 Para Raúl Bocanegra, Los montes vecinales en mano común. Naturaleza y régimen jurídico, IEAL, Madrid, 1986, pp. 42 y 43, los montes vecinales en mano común son recogidos como categoría jurídica por la Jurisprudencia civil, fundamentalmente generada en Galicia. Así, para este autor, «no es la titulación aportada en cada caso por las comunidades de vecinos para justificar su derecho... lo que provoca el reconocimiento judicial de una comunidad en mano común en el norte y noroeste de España..., sino precisamente esa sensibilidad judicial a la realidad social de esas regiones, en donde la peculiar repartición geográfica de los núcleos de población facilita la disociación entre las estructuras político-administrativas, y las sociales, en donde el común de los vecinos no ha evolucionado de la misma forma que en el resto de España, permaneciendo los municipios como entidades extrañas y lejanas a la realidad de todos los días, y en donde, tal vez por la misma dispersión geográfica, la conciencia de comunidad vecinal ha sido particularmente vigorosa». 


\section{B. La necesidad de una afectación comunal más rentable económica y socialmente. La afectación al fomento de la riqueza municipal y del empleo}

Los montes municipales, más concretamente los comunales, se pueden destinar o afectar al fomento de la riqueza municipal o del empleo ${ }^{50}$.

El carácter de bien económicamente explotable que tienen los montes (como ejemplo más típico de bienes comunales) ya se contenía en las Ordenanzas Generales de Montes de 1833 de Javier de Burgos (Gaceta de Madrid de 24 de diciembre de 1933), que definía a los montes en virtud de su utilidad económica. Así se establecía que:

- «Bajo la denominación de montes se comprenden los terrenos que puedan suministrar materiales útiles para la construcción civil o naval, carbón, combustibles y demás necesidades...»

Ese posible destino de los bienes comunales al fomento de la riqueza y del empleo pasa por eliminar una forma de explotación basada en la mera subsistencia de estos bienes ${ }^{51}$. Se necesita realizar una utilización de los montes comunales que permita la obtención de una buena rentabilidad de los mismos, lo que puede pasar por una explotación en forma de cooperativa.

Hay que tener en cuenta cómo la Comunidad Europea va en la línea de potenciar la explotación forestal como una alternativa para acometer la

\footnotetext{
${ }^{50}$ En este sentido, A. EmBid Irujo, La defensa de los comunales (Planteamientos generales a partir de la realidad aragonesa), Diputación provincial de Zaragoza, Ed. Civitas, S. A., Madrid, 1993, p. 45, sostiene la existencia de patrimonios públicos, como los comunales, utilizados como medios de intervención en la vida económica.
}

Por su parte, el Tribunal Supremo, en la Sentencia de 14 de noviembre de 1995 (Ar. 8567, Pte.: J. García Estartús), sostiene que los bienes comunales son bienes primariamente afectos a un fin social de promoción de la riqueza ante los más necesitados y de empleo (FJ $3 .^{\circ}$ de la sentencia apelada).

51 A. NiETo, Bienes comunales, op. cit., p. 891, sostiene que: «Los bienes comunales pueden constituir la base ideal para la futura explotación agraria de tipo corporativo». Así, para este autor, «la revolución industrial y técnica es compatible con las pequeñas propiedades, siempre que éstas se agrupen para formar unidades rentables de cultivo. Los labradores conservan su propiedad individualizada, pero para los cultivos se emplea una maquinaria común y un trabajo comunitario...».

Por su parte, Bocanegra Sierra, Los montes vecinales en mano común. Naturaleza y régimen jurídico, IEAL, Madrid, 1986, pp. 117-118, manifiesta que la Ley de 1980, reguladora de los montes vecinales en mano común, contiene una gran preocupación por obtener la máxima rentabilidad de estas propiedades, desprendiéndose de su utilización propia de una economía de subsistencia. 
reducción de los excedentes agrícolas que estaba poniendo en peligro las rentas de los agricultores 52 .

Por otra parte, la Ley de Protección de Montes o Terrenos Forestales de Andalucía viene a defender una correcta explotación de los montes públicos ${ }^{53}$, a fin de obtener una mayor rentabilidad social y económica de los mismos, lo que pasa por formas asociativas de explotación ${ }^{54}$.

Sin embargo, las ventajas que puede conllevar una explotación corporativa de los montes comunales choca con una línea interpretativa reacia del Tribunal Supremo. El tradicional disfrute colectivo por los vecinos de los aprovechamientos de los bienes comunales lleva a este Tribunal a no aceptar fórmulas de aprovechamientos más rentables propuestas por los Ayuntamientos.

En este sentido, con apoyo en una interpretación restrictiva de la normativa de régimen local estatal que regula el aprovechamiento de los bienes comunales, la Sentencia de 3 de mayo de $1989{ }^{55}$ niega la validez de una Ordenanza municipal sobre aprovechamiento de montes comunales del Ayuntamiento de Tineo (Asturias), que pretende primar a los vecinos que se constituyan en cooperativa o asociación.

El Ayuntamiento sostiene como fundamento de la aprobación de la susodicha ordenanza la aplicación de los principios del ordenamiento económico y el imperativo de que la riqueza ha de acomodarse a nuevas fórmulas actuales de explotación que la hagan más rentable, máxime cuando el fuerte despoblamiento de las áreas rurales aconseja una nueva normativa para toda esta actividad.

Este intento de rentabilizar la explotación económica de los bienes comunales por parte del municipio encuentra su freno en la doctrina sentada en esta sentencia por el Tribunal Supremo, el cual viene a sostener:

\footnotetext{
52 J. Esteve Pardo, Realidad y perspectivas de la ordenación jurídica de los montes (función ecológica y explotación racional), Generalitat de Catalunya. Ed. Civitas, S. A., 1995, pp. 163 y ss.

53 Entendiéndose por tales, de conformidad con el artículo 20 de la Ley 2/1992, de 15 de junio, «los pertenecientes a cualesquiera de las Administraciones y Entidades públicas», donde podríamos incluir los montes comunales.

${ }^{54}$ El artículo 67 de la Ley 2/1992, de 15 de junio, de Protección de montes o terrenos forestales de Andalucía, establece: «En la adjudicación de los aprovechamientos de los montes públicos habrá de prestarse especial consideración a los habitantes de las comunidades rurales de la zona, fomentándose las formas asociativas para la obtención de una mayor rentabilidad social y económica del monte».

${ }^{55}$ Sentencia de 3 de mayo de 1989 (Ar. 3641; Pte.: F. González Navarro).
} 
- Que dado que los bienes de cuya explotación se trata son bienes comunales, les son aplicables el artículo 79.3 de la LBRL, que los define como aquellos «cuyo aprovechamiento corresponde al común de los vecinos», el artículo 75 del TRRL y el artículo 94 del RBEL.

— Centrándose en el carácter obligatorio de los artículos 75 del TRRL y 94 del RBEL sostiene el Tribunal que el municipio debe respetar el orden de posibles aprovechamientos de los bienes comunales que se contiene en los mismos, y de los cuales se deduce que el aprovechamiento y disfrute de estos bienes se realizará: en primer lugar, en régimen de explotación común o cultivo colectivo; cuando tal disfrute fuere impracticable regirá la costumbre u ordenanza local; la adjudicación por lotes o suertes, si estas formas de aprovechamiento no fuesen posibles, se realizará por adjudicación mediante precio ${ }^{56}$.

- A la vista de esta regulación, el Tribunal Supremo considera que se está vulnerando con la citada ordenanza ese orden de prelación que debe regir el aprovechamiento de los bienes comunales «al primar a unos vecinos sobre otros (los que se constituyen en cooperativas), sustituyendo así el aprovechamiento común y directo por el interpuesto por persona jurídica. Además, considera el Tribunal que en defecto de ese aprovechamiento colectivo y común debe regir la costumbre local y no la ordenanza local.

- A todo ello añade que el legislador en la LBRL, TRRL y RBEL tuvo ocasión de formular nuevas formas de aprovechamiento y no lo hizo primando lo tradicional en cuanto a la explotación de los bienes comunales.

Esta sentencia merece ser criticada desde distintos puntos de vista:

- En primer lugar, para resolver el orden de prelación en los aprovechamientos de bienes comunales, se vale el Tribunal Supremo del artículo 75 TRRL y del RBEL (art. 94), que tienen mero carácter supletorio de la legislación autonómica en la materia.

Las Comunidades Autónomas que regulan el régimen de aprovechamientos de los bienes comunales vienen estableciendo el mismo orden de prelación que se deduce del TRRL (art. 75) y del RBEL (art. 94), dando siempre primacía a la explotación común o colectiva. Destaca por la ex-

${ }^{56}$ Esta misma prelación en orden a los posibles aprovechamientos de los bienes comunales se recoge en la STS de 18 de octubre de 1999 (Ar. 2005. Pte.: Ramón Trillo Torres; FJ 4. ${ }^{\circ}$ ), que niega la posibilidad de que se utilice la subasta como forma de adjudicación de aprovechamientos, ya que era posible la explotación común o cultivo colectivo. 
haustiva regulación del régimen de explotación de los bienes comunales y, por lo que de innovadora tiene en cuanto a tratar de conseguir la máxima rentabilidad en la explotación de los bienes comunales, la legislación sobre Administración local de Navarra de $1990{ }^{57}$.

- En segundo lugar, la interpretación del orden de aprovechamientos posibles de los bienes comunales, establecido tanto en la normativa estatal como autonómica (con la excepción de Navarra, que prevé un régimen peculiar de explotación), puede ser objeto de una interpretación más favorable a aumentar la rentabilidad en la explotación de los mismos.

Así, la obligación de que el aprovechamiento y disfrute de los bienes comunales se haga en «régimen de explotación común o colectiva» no impide que tal explotación común o cultivo colectivo venga regulado por el municipio mediante ordenanza ${ }^{58}$, la cual puede establecer la obligación de asociarse en cooperativas que tienen los vecinos a efectos de realizar una explotación de esos bienes más rentables para el municipio y que, al mismo tiempo, pueda generar empleo. Ello siempre que esta explotación cooperativista del bien no vulnere ese uso común al excluir a vecinos del correspondiente municipio.

Esa regulación municipal mediante ordenanza del aprovechamiento de bienes comunales, de forma común o colectiva, puede encontrar su apoyo en el derecho que ostentan a «intervenir en cuantos asuntos afecten directamente al círculo de sus intereses», conforme al artículo 2.1 de la LBRL.

\footnotetext{
57 Artículo 204 de la Ley de régimen local de Cataluña de 1987; artículo 43 de la Ley de Bienes de las Entidades locales de Andalucía, artículo 83 de la Ley de Administración Local de Aragón.

Frente a la obsoleta regulación que el TRRL — art. 75- y el RBEL — arts. 94 a 108 — realizan del régimen de utilización de los bienes comunales, siguiendo apegados a las típicas y tradicionales formas de aprovechamiento comunal, debido a la existencia de auténticos derechos vecinales a los aprovechamientos, Comunidades Autónomas como Navarra, al regular el régimen de aprovechamiento de los bienes comunales, opta por una explotación económica tendente a la consecución de los máximos recursos (arts. 141-176 de la Ley de 2 de julio de 1990 de Administración Local). Así, el artículo 141 establece que «las Entidades locales velarán por la puesta en producción, mejora y aprovechamiento óptimo de los comunales».
}

Para conseguir esa mejor explotación de los bienes comunales se arbitra un sistema de utilización que entraña la posibilidad de que el comunal sea aprovechado en forma no vecinal (sin necesidad de ser vecino) y vecinal, así como la ausencia de gratuidad en este tipo de aprovechamientos.

Sobre el aprovechamiento de los bienes comunales en Navarra, vid. Miguel Espaza Oroz, Comentarios a la Ley Foral de Administración Local de Navarra. Dirigidos por Martín M. Razquin Lizarraga, Ángel Serrano Azcona. Gobierno de Navarra. Departamento de Administración local. 1991, pp. 430 y ss.

58 Así, el artículo 95 del RBEL establece que «cada forma de aprovechamiento se ajustará, en su detalle, a las ordenanzas locales o normas consuetudinarias tradicionalmente observadas». 
- En tercer lugar, en caso de que no fuese posible ese aprovechamiento común o colectivo, se puede realizar un aprovechamiento conforme a la «costumbre u ordenanza local». No existe así preferencia en la costumbre sobre la ordenanza local ${ }^{59}$.

El Consejo de Estado también se ha pronunciado en reiteradas ocasiones, limitando la posibilidad de que una ordenanza municipal regule el aprovechamiento de bienes comunales de forma distinta al aprovechamiento «común o colectivo», cuando no exista prueba de que éste no es posible realizarlo ${ }^{60}$. Sin embargo, ha admitido formas de aprovechamiento de los bienes comunales más rentables para el municipio, impuestas a través de ordenanza, cuando el aprovechamiento que los vecinos venían realizando de los bienes comunales era por adjudicación de suertes o lotes (no en uso común o colectivo) ${ }^{61}$.

\section{RECAPITULACIÓN}

La persistencia histórica de unos bienes, los comunales, caracterizados por una constante falta de unanimidad en cuanto a la calificación de su naturaleza jurídica, tanto doctrinal como jurisprudencialmente, a pesar de los abundantes estudios que se centran en los mismos, nos ha llevado a fundamentar cuál sea nuestra postura al respecto.

Así, del análisis de su actual regulación y, fundamentalmente de la línea seguida en esta materia por las Comunidades Autónomas que han dictado legislación sobre los bienes locales, concluimos que la naturaleza

59 Sin embargo, el Tribunal Supremo, en su Sentencia de 29 de diciembre de 1998 (Ar. 10295; Pte.: Rodolfo Soto Vázquez, FJ 2. ${ }^{\circ}$ ), sostiene, con apoyo en el artículo 75.2 del TRRL'86, el valor prevalente de la costumbre sobre las ordenanzas locales en materia de aprovechamiento y disfrute de bienes comunales.

En contraposición a esta Sentencia la de 24 de abril del 2000 (Ar. 3818; Pte.: Antonio Martí García; FJ $3 .^{\circ}$ ) y la de 11 de abril del 2000 (Ar. 4439; Pte.: Antonio Martí García; FJ 3. ${ }^{\circ}$ ), interpretando el artículo 75.2 del TRRL, sostiene la no prevalencia de la costumbre sobre la Ordenanza local, considerando perfectamente válida una ordenanza relativa al aprovechamiento de un bien comunal.

${ }^{60} \mathrm{Vid}$. el Dictamen de 19 de octubre de 1989 (n. ${ }^{\circ}$ 53601), relativo a una ordenanza sobre aprovechamiento de bienes comunales, y el Dictamen 429/94, de 2 de junio.

${ }^{61}$ Dictamen 2353/95, de 11 de enero, en Consejo de Estado. Recopilación de Doctrina legal, 1996, pp. 549 y ss. Este dictamen sostiene la conformidad a derecho de una ordenanza para aprovechamientos de pinos del Ayuntamiento de Neila (Burgos), que prevé un sistema de aprovechamientos más rentable para los titulares, distribuyendo entre los mismos no la suerte (el derecho a la tala), sino el producto de la enajenación de la madera. Así, el Ayuntamiento, mediante una comisión vecinal gestora, contrata la tala y enajenación de la madera a fin de garantizar un mejor aprovechamiento económico del bien. 
de los bienes comunales no puede ser otra que la demanial. A esto no cabe objetar que faltan los elementos propios de los bienes de dominio público, como sean la titularidad administrativa o la afectación a un uso o servicio público. Y ello porque no existen pronunciamientos expresos en la normativa estatal o autonómica reguladora de estos bienes, manteniendo la titularidad vecinal o compartida entre municipios y vecinos. Así, estos tipos de titularidades se encuentran recogidos a nivel jurisprudencial, lo cual no supone una doctrina reiterada desde el momento en que encontramos pronunciamientos sobre la titularidad de los comunales, que cambian al son de los cambios de posturas doctrinales.

Por otro lado, tampoco el hecho de que los bienes comunales no se encuentren afectos a un uso o servicio público sirve para negar su naturaleza demanial, ya que a nivel de bienes municipales hemos de admitir otro tipo de afectación, la propia de los bienes comunales, o sea, «el aprovechamiento y disfrute por los vecinos». En consecuencia, existen tres afectaciones en los bienes municipales: a un uso público, a un servicio público y al aprovechamiento vecinal, lo que hace variar el régimen jurídico de los bienes de dominio público municipal, fundamentalmente en cuanto a su régimen de aprovechamiento.

Para mantener que la titularidad de los bienes comunales es vecinal o, la postura más extendida, que es compartida, y negar su naturaleza de bien de dominio público municipal, amparándose, además, en que su afectación no es a un uso o servicio público, sería necesario una reforma del artículo 80 de la LBRL'85, del que parece inferirse la naturaleza demanial de este tipo de bienes, así como del artículo 2, apartados $3 .^{\circ}$ y $4 .^{\circ}$ del RBEL' 86 , en los que se afirma el carácter demanial de dichos bienes y su titularidad municipal o de los Entes Locales Menores, respectivamente. Reforma que debería ser seguida por las legislaciones autonómicas, que con claridad y rotundidad incluyen a los bienes comunales como bienes de dominio público.

Por otro lado, en cuanto al rasgo típico de los bienes comunales, cual es su afectación al aprovechamiento vecinal, se hace necesario, bien una reforma de la normativa reguladora de dicho aprovechamiento o, simplemente, una interpretación del Tribunal Supremo más flexible en cuanto al sistema típico de aprovechamiento de estos bienes, que no es otro que la «explotación colectiva o comunal», lo que implica un disfrute general y simultáneo de los bienes por quienes ostenten la condición de vecinos. Y ello en la medida en que se hace necesario cumplir el principio recogido en el Código Civil de interpretación de las normas de conformidad con la realidad social de cada momento (art. $3 \mathrm{CC}$ ). Y parece claro que, si bien 
es lógico mantener un sistema de explotación tradicional, que es, además, la razón de existir de los bienes comunales, también parece lógico que ello no debe impedir que el municipio como propietario de dichos bienes pretenda obtener la máxima rentabilidad de los mismos, lo cual va a repercutir directamente sobre los vecinos.

Así, el municipio debe poder adoptar las Ordenanzas que estime pertinentes en orden al correcto «uso o explotación común de dichos bienes», siempre que lo oriente hacia una mejora social y del empleo de los vecinos del municipio. Ello tiene su fundamento en una potenciación «real» de la AUTONOMÍA MUNICIPAL, que actualmente ha sido tan reivindicada y que ha obtenido algunos frutos a través del llamado «Pacto Local», que ha conllevado las sabidas reformas en el régimen local. 
